\title{
Sociálna štruktúra $v$ detskej skupine a sociálny habitus predškolských detí
}

\section{Social Structure of Children's Groups and the Social Habitus of Preschool Children}

\author{
Martin Kanovský, Monika Turanská
}

\begin{abstract}
SUMMARY The aim of this article is to assess empirically the various ways that preschool children in their peer groups create, maintain and reproduce their social relations, how they represent them and how hierarchical social structure in children's peer groups is maintained and represented. The dependent variable is linear hierarchical rank based on participant observation of dyadic agonistic interactions among children. Our independent variables are executive functions of children on the one hand, and their socioeconomic status on the other. Due to non-normal distribution of the sample, robust statistical methods have been used in analysis. The results show that there is strong positive correlation between executive functions and hierarchical rank, but there is no correlation between socio-economic status and hierarchical rank. The conclusion is that children develop and maintain their executive functions in their peer groups, rather than in their families.
\end{abstract}

KEYWORDS Preschool peer groups, social hierarchy, executive functions, socio-economic status

\section{Úvod}

Ciel'om tohto príspevku je teoreticky vyložit' a najmä empiricky preskúmat' spôsoby, ako si deti vo svojej rovesníckej skupine svojimi praktikami a reprezentáciami vytvárajú, budujú a reprodukujú sociálne vzt'ahy, ako ich vnímajú a udržujú, a ako sa vlastne v detskej skupine vytvára a reprodukuje sociálna štruktúra a čo ju ovplyvňuje. Pokúsime sa prepojit’ bourdieuovskú koncepciu sociálnych praktík a sociálneho habitusu s kognitívnymi teóriami a doložit' produktívnost' tohto prepojenia na konkrétnych príkladoch z terénneho výskumu. Zároveň by sme chceli ilustrovat' produktívnost' kombinovania kvalitatívnych, etnografických metód dlhodobého terénneho výskumu a zúčastneného pozorovania s experimentálnymi technikami kognitívnej psychológie a antropológie, ako aj s pokročilými (robustnými) štatistickými metódami.

Skúmanie detských kultúr a detských skupín je jednou z najdôležitejších a najzaujímavejších výskumných tém, napriek tomu sa nedá povedat', že by v sociálnych vedách

Sociální studia. Katedra sociologie FSS MU, 2/2014. S. 13-26. ISSN 1214-813X.

1 Tento článok vznikol vd’aka podpore v rámci OP Výskum a vývoj pre dopytovo-orientovaný projekt: Univerzitný vedecký park Univerzity Komenského v Bratislave, ITMS 26240220086 spolufinancovaný zo zdrojov Európskeho fondu regionálneho rozvoja. Podporujeme výskumné aktivity na Slovensku/Projekt je spolufinancovaný zo zdrojov EÚ. 
(s výnimkou vývinovej psychológie) bol relevantne zastúpený (Christensen a James 2008; Corsaro 2003; Hirschfeld 2002). Deti, ich skupiny a subkultúry sú navyše sociálne skúmané z epistemologicky a metodologicky dost' pochybných perspektív, medzi ktorými dominujú najmä dva skôr implicitné, no o to húževnatejšie predpoklady: po prvé, za najdôležitejšie zdroje informácií o det'och sú ešte stále považovaní dospelí, najmä rodičia, ale aj učitelia, vychovávatelia, starší súrodenci, opatrovatelia; a po druhé, vychádza sa z predpokladu, že deti (nedokonalým spôsobom, s ustavičnými korekciami a inštrukciami) pasívne napodobňujú a preberajú kultúru dospelých prostredníctvom priamych inštrukcií, príkazov a zákazov.

$\mathrm{V}$ tomto príspevku nemienime priamo vyvracat' tieto predpoklady teoretickou diskusiou, ale nastolit' a otestovat' iný predpoklad: deti tvoria diferencovanú sociálnu skupinu, majú svoju detskú subkultúru, ktorá sa riadi vlastnými pravidlami, spôsobmi správania sa a platia v nej špecifické sociálne vzt’ahy. Deti sú vel'mi vnímavé voči týmto sociálnym vzt’ahom, dokážu si osvojit' a rešpektovat' komplexné a komplikované sociálne vzt’ahy vo vlastnej detskej skupine. Štruktúra detskej skupiny je diferencovaná a pre deti je nesmierne dôležité, aby boli v skupine rešpektované inými det'mi, čomu podriad'ujú svoje správanie a predstavy podstatne viac než správaniu a predstavám dospelých, vrátane rodičov.

Osvojovat' si a sociálnymi praktikami reprodukovat' diferencovanú štruktúru sociálnej skupiny, alebo, bourdieuovskými slovami, nadobúdat' sociálny habitus inkorporovanými spôsobmi - tieto procesy sa neodohrávajú $\mathrm{v}$ abstraktnej prázdnote ideálnych typov ani vo vágnych odkazoch na intuitívne makropojmy typu „telesnost'/telo“, ,rodina“, ,spoločnost"“ atd'. Je potrebné uznat' a špecifikovat' nielen to, že sociálny habitus je inkorporovaný, ale aj to, ako sa to deje, ako napokon vel'mi jasne uvádza Bourdieu (1991):

„Bolo mi jasné, že ak sa má vysvetlit’ takmer zázračná a až neuveritel'ná nevyhnutnost’ bez akéhokol’vek organizujúceho zámeru, odhalená analýzou, musí sa prihliadnut' k vteleným dispozíciám [...] aby sa ukázal organizujúci princíp [...] schopný orientovat' praktiky spôsobom, ktorý je zároveň nevedomý i systematický“" (Bourdieu 1991: 9-10).

V tomto príspevku sa pokúsime preskúmat' prepojenie medzi tromi nezávisle skúmanými javmi: sociálnou hierarchiou v detskej rovesníckej skupine (Russon a Waite 1991), sociálnym habitusom detí, inkorporovanom exekutívnymi funkciami (Bourdieu 1986, 1990, 1998; Bourdieu a Passeron 1990; Diamond 2013), a socioekonomickým statusom detí (Lareau 2011). Vychádzame teda z predpokladu, že sociálny habitus (v Bourdieuho zmysle) sa inkorporuje prostredníctvom toho, čo sa v kognitívnej psychológii nazýva „exekutívne funkcie“: psychologický dispozičný konštrukt dokázatel’ne ovplyvňujúci praktiky a behaviorálne regulácie prostredníctvom svojich zložiek: pracovnej pamäti, pozornosti a inhibičnej funkcie (Diamond 2013).

Nechceme samozrejme tvrdit', že Bourdieuho komplexný pojem sociálneho habitusu je psychologicky a kognitívne inkorporovaný a implementovaný výhradne a výlučne exekutívnymi funkciami: a ani to, že exekutívne funkcie implementujú výhradne a výlučne sociálny habitus. Naša hypotéza je ovel’a skromnejšia - tvrdíme iba to, že sociálny habitus je (okrem iného) implementovaný (čiastočne aj) exekutívnymi funkciami. Dnes už nie je potrebné špeciálne zdôvodňovat', že sociálny habitus musí mat' kognitívnu implementáciu, pretože je to považované za samozrejmost' (Lizardo 2004; Cerulo 2002; DiMaggio 2002). Málo pozornosti 
sa však venuje špecifickému popisu presných kognitívnych funkcií, ktoré sú za túto implementáciu zodpovedné.

\section{Sociálna hierarchia, exekutívne funkcie a socioekonomický status}

Pre deti, rovnako ako pre iných sociálnych aktérov, je dôležité presadit' sa, získat' určitý status a rešpekt: diet'a chce byt' vo svojej sociálnej skupine uznávané, rešpektované a chce presadzovat' svoju vôl'u pri konkrétnych praktikách. Nechceme tvrdit', že det'om ide o moc, autoritu či o výsadné postavenie v detskej skupine: každé diet’a však má určité predstavy o svojom postavení a činnostiach a snaží sa správat' podl'a týchto predstáv. Sociálne praktiky, o ktorých budeme v tomto texte hovorit', teda behaviorálna hierarchia ani zd'aleka nevyčerpáva. Existuje mnoho zložitých sociálnych a emocionálnych väzieb medzi det'mi v skupine a sociálna hierarchia nie je vôbec jedinou z nich: napríklad afektívno-emocionálne vzt’ahy priatel'stva alebo reprezentačné vzt'ahy prestíže a uznania sa môžu prelínat' a navzájom ovplyvňovat' s behaviorálnou hierarchiou - avšak vzhl'adom na to, že nás primárne zaujímajú sociálne praktiky (a nie emocionálne či prestížno-symbolické vzt'ahy, ktorých dôležitost' nepopierame), sústredili sme sa na behaviorálne prejavy dominancie a submisie medzi det'mi. Zaujímajú nás primárne agonistické vzt’ahy (Hymel et al. 1990; Russon a Waite 1991; Killen 1991), teda vzt’ahy, ktoré sú dyadické (vždy sa odohrávajú medzi dvomi det'mi) a v ktorých sa jedno diet'a snaží vnútit' svoju vôl'u druhému prostredníctvom konkrétnej, pozorovatel'nej sociálnej praktiky (tá nemusí byt' nevyhnutne agresívna). Je zrejmé, že tieto druhy vzt’ahov sa týkajú skôr behaviorálnej dominancie než emocionálnych vzt'ahov (diet’a môže mat' obl'úbených priatel'ov, ktorých neposlúchne, a naopak, môže poslúchnut' deti, ktoré vôbec nezarad'uje medzi priatel'ov). V detskej skupine sa vytvára zložitá hierarchická štruktúra, ale my sa sústredíme iba na jeden jej aspekt - lineárne hierarchické usporiadanie. Nijako nepopierame, že táto koncepcia je inšpirovaná evolučnou antropológiou a etologickými výskumami, pri ktorých sa ovel'a väčší dôraz kladie na pozorovatel'né praktiky, ako reprezentácie či emocionálno-afektívne stavy.

Ked’že ide o pozorovanie a analýzu správania, teda pozorovatel'ných behaviorálnych praktík, sledujú sa zúčastneným pozorovaním situácie, počas ktorých prišlo medzi dvojicami detí $\mathrm{k}$ hádke, konfliktu, a jedno $\mathrm{z}$ detí vyšlo z tejto situácie ako vít’az a druhé ako porazené. V detskej rovesníckej skupine je zvyčajne vel'mi intenzívne zastúpená sút’aživost', pretože deti súperia o obmedzený počet zdrojov rozličných druhov. To vedie $\mathrm{k}$ nastoleniu určitej hierarchie: niektoré deti sú dominantnejšie, iné sa skôr podriad’ujú: „Dominantné vzt'ahy sú typické pre dyády, dominantný je ten partner, ktorý má neustále prednost', vyhráva, alebo kontroluje či limituje správanie druhého jedinca, toho podriadeného" (Russon a Waite 1991: 58).

Ďalším kl’účovým pojmom sú exekutivne funkcie, ktoré sú podl'a nás spôsobom, akým je psychologicky inkorporovaný sociálny habitus detí. Diamond (2013) predstavuje tri hlavné zložky exekutívnych funkcií: inhibícia, pracovná pamät’ a pozornost'. Inhibičná kontrola, ktorá je nesmierne náročná najmä pre malé deti, zahŕňa sebaovládanie, vd'aka ktorému dokážu zadržat' svoje impulzívne a okamžité reakcie, potlačit' nepríjemné, nežiaduce a rozptyl'ujúce myšlienky a spomienky, a nenechat' sa vyrušovat', resp. odolat' pokušeniu 
a rozptýleniu. Je zrejmé, že pri inkorporácii sociálneho habitusu ide o kl'účovú schopnost': sociálne normy sa napospol týkajú kontroly inštinktov a bezprostredných podnetov. Pracovná pamät' (working memory), ,je rozhodujúca pre našu schopnost' vidiet' spojenie medzi zdanlivo nesúvisiacimi vecami a oddelit' časti z jednotného celku" (Diamond 2013: 143). Tretia čast' je pozornost', schopnost' zamerat' sa na určitú činnost' a vytrvat' pri nej. Opät', netreba špeciálne zdôvodňovat', že pre inkorporáciu sociálneho habitusu ide o zásadnú schopnost'. I ked' na meranie exekutívnych funkcií existuje vel'a metód, my sme si zvolili, najmä kvôli svojej reliabilite a popularite $\mathrm{v}$ našom kultúrnom prostredí, metódu HTKS, ktorá je adaptáciou známej detskej riekanky „Hlava - ramená - kolená - palce“ (Wanless et al. 2011). Podrobný opis tejto metódy uvádzame v d’alšej časti.

Pokial' ide o pojem habitus, ten je $\mathrm{v}$ sociálnych vedách dostatočne známy (Bourdieu 1986, 1990, 1998). Sociálny kapitál Bourdieu charakterizuje ako „súhrn aktuálnych alebo potenciálnych zdrojov, ktoré sú spojené s vlastníctvom trvalej siete viac alebo menej inštitucionalizovaných vzt’ahov vzájomnej známosti a poznania - alebo inými slovami s členstvom v skupine“ (Bourdieu 1986: 51). Naša koncepcia vychádza z predpokladu, že pri skúmaní sociálneho kapitálu detí sa významný (takmer výlučný) dôraz kladie na rodinné prostredie a sociálne siete dospelých, v ktorých sú deti akýsi prídavok, a takmer nejestvujú výskumy, ktoré by konceptualizovali a empiricky skúmali sociálny kapitál, ktorý deti nadobúdajú v detských skupinách. Sociálny habitus, ktorý inkorporujuje sociálny kapitál, je trvalou (hoci transformujúcou sa) sociálnou dispozíciou k určitému typu správania, ktorú človek získava, ked’ sa pohybuje v určitej sociálnej pozícii a v určitej sociálnej skupine: „Habitus je generatívny a jednotiaci princíp, ktorý z charakteristických vzt’ahových rysov, vlastných určitému postaveniu, vytvára jednotný životný štýl, to jest celok, v ktorom sa zjednocuje vol'ba osôb, statkov a praktických činností. Habitusy, rovnako ako spoločenské pozície, ktorých sú plodom, sú diferencované; tiež však diferencujú" (Bourdieu 1998: 33). Ak súhlasíme s týmto vymedzením, je zrejmé, že pobyt dietata $\mathrm{v}$ detskej skupine musí zásadným spôsobom ovplyvňovat' vytváranie sociálneho habitusu.

Nechceme však popierat', že rodinné prostredia a sociálna stratifikácia rodín majú dôležitý vplyv. Výskumy Lareau (2011) aj mnohých iných (v našich podmienkach napríklad Katrňák 2004) ukázali, že aj rodinné prostredie a najmä praktiky v ňom, určujú sociálny habitus detí. Je potrebné brat' do úvahy rozdiely v tom, ako rodičia vychovávajú svoje deti a aké organizačné praktiky $\mathrm{k}$ tomu používajú. Niektorí rodičia sú vel'mi zaneprázdnení a aktivity si plánujú dopredu, považujú však za dôležité, aby deti navštevovali rôzne krúžky, diskutujú s nimi na rôzne témy, zaujímajú sa o ich štúdium. Iní rodičia sa o svoje deti tiež starajú a stanovujú im určité hranice, ale ich dohl’ad nad nimi, disciplinácia a pedagogická práca sú ovel'a menšie. Preto niektoré deti, napriek tomu, že sú viac vystavené stresom, sú vyčerpanejšie a kladú sa na ne väčšie nároky, sú aj lepšie pripravené na disciplinačné inštitúcie ako škola a neskôr práca, pretože ich na to pripraví spôsob, akým boli vychovávané, disciplinované - teda primárna pedagogická práca rodičov. Nechat' deti vyrastat' bez primárnej pedagogickej disciplinácie je spôsob výchovy, ktorý je vzdialenejší školskému systému, preto takéto deti majú st’ažený vstup do vzdelávacích inštitúcií alebo neskôr do práce. Tieto rozdiely sa v bežnom, ale aj v mediálnom a pedagogickom diskurze psychologizujú či 
dokonca biologizujú (ideologický diskurz „talentu, nadaných deti'“ v protiklade k „zaostalým, zanedbaným det’om“).

V tomto príspevku sa sústredíme na to, aby sme na základe jednej prípadovej štúdie preskúmali (pomocou kvalitatívnych i kvantitatívnych metód) vzt’ahy medzi tromi premennými: behaviorálna hierarchia $\mathrm{v}$ detskej skupine, exekutívne funkcie detí (teda inkorporovaný sociálny habitus) a socioekonomický status rodín detí. Chceme ukázat', že exekutívne funkcie detí významne korelujú skôr s behaviorálnou hierarchiou v detskej skupine než so socioekonomických statusom rodín. Inými slovami povedané, sociálny habitus detí sa rozvíja a v ovel’a väššej miere sa prispôsobuje detskej skupine než rodinnému prostrediu.

\section{Lokalita, výskumná vzorka a metódy výskumu}

Výskumnou lokalitou pre tento výskum bola vybraná jedna materská škola v hlavnom meste. Výskumnú vzorku tvorilo 21 detí, ktorých priemerný vek bol 5,4 (SD = 0,8). Z 21 detí býva 16 priamo v mestskej časti. Dve deti mali čínskych rodičov, po slovensky síce tieto deti rozumeli vel'mi dobre, ale skoro vôbec nerozprávali. Všetky ostatné deti mali slovenskú národnost'. Účastníkmi výskumu boli okrem detí aj ich rodičia a dve učitel'ky triedy.

Údaje o sociálnej hierarchii boli získané zúčastneným pozorovaním, ktoré trvalo 4 týždne (28 dní). Zúčastnené pozorovanie začínalo ráno v čase, ked’ deti s rodičmi prichádzali do škôlky, a končilo po obede po povinnom oddychu, ked' v triede ostávalo iba niekol'ko detí a vybranú triedu spájali s ostatnými triedami materskej školy (interakcie detí s det’mi $\mathrm{z}$ iných tried neboli zaznamenávané). Zúčastnené pozorovanie sa vykonávalo výhradne počas detských aktivít, ktoré sa diali vo vol'nom čase, kedy nemali organizovaný program učitel'kou. Tieto aktivity sa mohli diat' či už vnútri alebo vonku. Ako dyadické interakcie boli zaznamenávané iba interakcie dvojíc detí bez zásahov učitel'ky. Ako už bolo uvedené, zaznamenávali sa iba agonistické dyadické interakcie (teda dalo sa určit', ktoré diet’a dominovalo). Príklady:

- DK poslal MJ preč z deky

- TR vzal lopatku $M H$

- DK poslal CY preč z miesta na strome

- DK zobral „plyšáka“ MJ

- IA si sadla na stoličku, prišla MM a prikázala jej, aby ju pustila si sadnút', IA sa zdvihla a odišla

- TR s JS stavali bunker, TR sa nepáčilo, ako JS stavia, tak ho poslal preč, nech sa ide hrat' sám, JS odišiel

- na obede sedeli JS a MT vedl'a seba, JS ho začal bit' rukami po hlave, MT mal len zavreté oči a ani sa nepohol, až kým nezasiahla učitel'ka

_ na ihrisku sa dievčatá šmýkali na šmyklavke, stáli v rade, MM prišla za SP, chytila ju za ruku, odtiahla preč a postavila sa na jej miesto, SP sa zaradila na koniec radu

- PB sa hrala s plyšovou hračkou, prišiel k nej TN a hračku jej vytrhol z rúk, PB si vzala inú a hrala sa d'alej 
Vít'azné diet'a sa teda presadilo a druhé diet'a z dvojice sa mu podriadilo. Ešte je potrebné vysvetlit' d'alšiu vec: presadenie sa a podriadenie sa, podl'a ktorých sa určuje hierarchia, sú behaviorálne pozorovanými epizódami bez zasahovania dospelých. Deti teda vyhodnocujú iba vzájomné vzt’ahy a neberú do úvahy možné zasahovanie dospelých (nepopierame dôležitost' zásahov dospelých, no v tejto štúdii sa im nevenujeme). Zaznamenávali sa všetky takéto situácie a vytvorila sa matica interakcií: tabul'ka, kde sú deti zoradené v stĺpcoch a riadkoch podl'a počtu dominancií a submisií. Existuje viacero spôsobov, ako kvantifikovat' hierarchický rank (umiestnenie) v takejto sociálnej skupine na základe dyadických agonistických vzt’ahov (Jameson et al. 1999; Albers a de Vries 2001; Gammell et al. 2003). Je zrejmé, že nemožno použit’ prostý rozdiel „vít’azstvá - prehry“: viedlo by to $\mathrm{k}$ tomu, že na vysokých pozíciách by sa mohli ocitnút' deti, ktoré mnohokrát opakovane dominovali nad vel'mi malým počtom iných detí. O niečo presnejšia je metóda váhovania: skóre dominancií (a submisií) sa nastaví tak, že maximálne skóre získané z jednej dyadickej interakcie bude 3: takže ak aj diet'a dominovalo nad konkrétnym iným diet'at'om povedzme 17-krát, aj tak bude jeho/jej skóre 3. Toto váhovanie bonifikuje deti, ktoré (aj ked's menším počtom epizód) sú schopné dominovat' nad čo najvyšším počtom iných detí, čo je vel'mi želatel'ná vlastnost' pre kvantifikáciu hierarchického ranku (Kanovský a Struková 2013). Avšak aj táto metóda má jeden deficit: nezohl'adňuje, nebonifikuje ani nepenalizuje to, nad ktorými det'mi dané diet'a dominuje či ktorým sa podriad'uje - už prostá úvaha odhalí, že dominovat' nad vel'mi submisívnym diet'at'om zjavne zahŕňa ovel'a menej nákladov a rizika, než dominovat' nad diet'at'om, ktoré je samo ovel'a dominantnejšie. A práve túto vlastnost' má „Davidovo skóre“: v ňom sa počíta na základe dyadických interakcií pravdepodobnost' vít’azstva (alebo prehry) pre každú dvojicu, následne sa určí primárny rank vít’azstiev a prehier, a ten sa použije na výpočet bonifikácie a penalizácie toho, nad ktorým diet'at'om dané diet’a dominuje či ktorému sa podrobuje. Výsledné skóre je súčtom primárneho skóre dominancie a bonifikácie za dominanciu, od ktorého sa odráta primárne skóre submisie a penalizácia za submisiu. Technické detaily odkazujeme na literatúru (David 1987; Gammell et al. 2003). Výsledkom je skóre lineárnej hierarchie v skupine, numerická škála. Chceli by sme ešte raz upozornit', že takto charakterizovaná lineárna hierarchia je presne definovaným technickým termínom a nie je možné ju neproblematicky rozšírit’ na iné chápanie „sociálnej hierachie", moci či autority.

Ďalšou meranou premennou je testovanie exekutívnych funkcií detí metódou HTKS (Cameron-Ponitz et al. 2008; Wanless et al. 2011; Tominey a McClelland 2011). Ide o (validizovanú) experimentálnu metódu merania využívajúcu hru „Hlava-prsty (na nohách)-kolená-ramená: Head-Toes-Knees-Shoulders, v našich podmienkach aj vo verzii „hlava-ramená-kolená-palce“, často v spievanej verzii). Metóda HTKS spočíva v tom, že det’om sa najskôr vysvetlia inštrukcie, podl'a ktorých majú postupovat'. Sú požiadané sa najprv dotknút' hlavy, potom sa dotknút' palcov na nohách, následne kolien a potom ramien/pliec. Po osvojení, vyskúšaní a habitualizácii sú následne inštrukcie pozmenené na kontrastný konflikt medzi verbálnou inštrukciou a behaviorálnym prejavom: deti sú inštruované, aby sa pri verbálnom pokyne „hlava“ dotkli prstov na nohách (a naopak), a pri verbálnom pokyne „kolená“ dotkli ramien (a naopak). Testuje sa samozrejme inhibičná funkcia (schopnost' inhibovat' pôvodnú behaviorálnu reakciu na podnet a presmerovat' ju), pracovná pamät' (diet'a musí memorizovat' 
a využívat' tak pôvodné inštrukcie a verbálne pokyny, ako aj ich prevrátené verzie) a pozornost'. Po habituácii sa v testovacej fáze zadáva 20 kôl inštrukcií ( 2 x 10 náhodne vybraných dvojíc hlava - prsty, kolená - ramená). Deti sú skórované nasledovne: 0 bodov za neúspech, 2 body za úspech, 1 bod za behaviorálny prejav smerujúci podl'a pôvodných inštrukcií (pri verbálnom pokyne ,hlava“ k hlave), no nedokončený a presmerovaný (k prstom na nohách). Celkové skóre môže dosiahnut’ na numerickej škále: 0 - 40 bodov.

Tretím súborom údajov je socioekonomický status rodiny diet'at’a. Počas dvoch týždňov sa uskutočnili pološtrukturované rozhovory s učitel'kami a rodičmi. S obomi učitel'kami sa uskutočnili opakované hĺbkové pološtruktúrované rozhovory, z ktorých každý trval viac než dve hodiny. S rodičmi (vždy iba s jedným z rodičov) sa uskutočnili jednorazové pološtruktúrované rozhovory, ktoré trvali jednu hodinu. Témami rozhovorov boli bytové pomery (sociálny byt - bývanie v podnájme - vlastný byt - rodinný dom), počet členov domácnosti, trávenie vol'ného času a víkendov, trajektória zamestnaní a súčasné povolanie, povolanie partnera, majetkové pomery a príjmy, miesto a frekvencia dovoleniek.

Na základe týchto informácií boli deti rozdelené do troch úrovní socioekonomického statusu (SES): vyšší, stredný a nižší. Napríklad kombinácia splnenia kritérií „rodinný dom / majitel’ IT firmy / nadpriemerné príjmy / letné a zimné dovolenky v zahraničí / automobil (alebo viac) prémiových značiek“ viedla k zaradeniu do „vyššieho SES“, kým kombinácia kritérií ,byt v panelovom dome / robotnícke a technické profesie (šofér/predavačka) / priemerné príjmy / dovolenky na Slovensku“ viedla k zaradeniu „stredný SES“, a kombinácia „podnájom / sociálny byt / nezamestnaný rodič či osamelý rodič v podpriemerne platenom zamestnaní / čast’ príjmov zo sociálnych dávok a podpôr / dovolenka (iba) u starých rodičov alebo žiadna“ viedla k zaradeniu „nižší SES“. Na zaradenie do danej úrovne muselo byt' splnených minimálne 4 zo 6 kritérií. (Tu uvádzame niektoré príklady profilov vybraných detí):

JS (vyšší SES)

JS je v triede najstarší, má šest' rokov a v septembri nastupuje do školy. Rodinu tvorí matka, otec, $J S$, jeho o rok starši brat a starši nevlastný brat, ktorý s nimi v domácnosti nežije, ale s ktorým má podl'a slov učitel'ky aj matky vel'mi dobrý vzt’ah. Z rozhovoru s matkou vyplynulo, že žijú priamo $v$ skúmanej lokalite, $v$ rodinnom dome, kde obaja rodičia prevádzkujú aj svoju IT firmu. Obaja majú vyštudovanú vysokú školu technického zamerania. Podl'a učitel'ky sú rodičia pravidelnými a hlavnými sponzormi škôlky, dokonca aj ked’ JS v septembri nastupuje do školy, venovali škôlke na d'alši rok rôzne elektronické pomôcky a hračky. Z rozhovoru s matkou vyplýva, že v lete chodieva celá rodina k moru, väčšinou sú to krajiny ako Chorvátsko, Grécko. V zime sa chodia lyžovat' bud' do Tatier alebo do rakúskych Álp.

DK (vyšší SES)

DK má pät’ rokov a žije v rodine pozostávajúcej z otca a o tri roky staršieho brata. Podl'a učitel'ky od nich matka odišla krátko po narodeni DK. Učitel'ka v rozhovore spomenula, že v byte žijú spoločne s opatrovatel'kou, ktorá sa počas dňa aj noci stará o t’ažko chorého DK, ktorý musí pravidelne brat' lieky a v noci máva často záchvaty spojené so st’aženým dýchaním. Občas vynecháva škôlku, ked’že musí byt' hospitalizovaný. Jeho staršiemu bratovi pomáha so školou doučovatel'ka, ktorá k nim chodí každý deň. Žijú v štvorizbovom byte priamo vo výskumnej lokalite. Otec má vyštudovanú vysokú školu, je podnikatel', vo výskumnej lokalite vlastní reštauráciu, kde 
trávi väčšinu času. Ako sám tvrdí, momentálne si otvára realitnú kanceláriu. V rozhovore spomenul, že na letnú dovolenku chodievajú pravidelne do Turecka a do Chorvátska, pričom vyberajú hotely najmä podl'a dostupnosti najbližšej nemocnice a samozrejmost'ou je, že s nimi chodi aj opatrovatel'ka DK.

$\mathrm{AD}$ (stredný SES)

Pätročný AD býva spolu s matkou a starými rodičmi v byte vo výskumnej lokalite. Podl'a slov učitel'ky otec s nimi nežije, a ani sa s AD nestretáva. Matka pracuje v telekomunikáciách ako vedúca oddelenia. O AD sa okrem nej starajú starí rodičia. V minulosti prekonal vážnu chorobu, museli ho operovat' a musel sa naučit' znovu rozprávat'. Čo sa týka dovoleniek, matka v rozhovore povedala, že chodieva v lete so starými rodičmi na chatu, alebo si urobia výlet po Slovensku, pri mori ešte nebol.

MJ (stredný SES)

MJ má pät' rokov a žije len s matkou v dvojizbovom byte vo výskumnej lokalite. Podl'a učiteliek matka s otcom neboli zosobášení a MJ sa s otcom stretáva len sporadicky. Z rozhovoru s matkou vyplýva, že pracuje ako vedúca na ekonomickom oddelení. Snaži sa byt’s MJ čo najčastejšie, no ak je v práci, je s ním jeho stará matka. Čo sa týka dovoleniek alebo víkendov, podl'a matky ich trávia väčšinou u starých rodičov, tento rok boli prvýkrát pri mori v Chorvátsku, nakol'ko MJ je alergik a pobyt pri mori by mu mal zlepšit' zdravotný stav.

\section{PN (nižší SES)}

PN má pät' rokov a s matkou žije v podnájme. V škôlke ostával vždy najdlhšie zo všetkých, odchádzal ako posledný. Matka pracuje ako predavačka v potravinách, často sa stane, že po syna nestíha prist', a učitel'ky s ním bud' ostávajú v triede dlhšie, alebo si ho vezmú na chvilu k sebe domov. Rodičia sú rozvedení, za otcom, ktorý býva mimo mesta, chodi každé dva týždne. Podl'a matky strávil celé leto u starých rodičov na dedine.

\section{SP (nižší SES)}

Pätročná SP žije s otcom, matkou, dvomi staršimi sestrami v sociálnych bytoch blizko škôlky. Otec pracuje ako robotnik, matka je zdravotná sestra. Otec je vraj alkoholik, ktorý bije matku a staršie sestry kvôli tomu často utekajú z domu (informácia od učitel'ky). Väčšinou to bol otec, kto SP priviedol aj odviedol zo škôlky. Z rozhovoru s otcom vyplynulo, že cez letné prázdniny ostávajú v Bratislave, pri mori neboli a taktiež nechodia na výlety po Slovensku, väčšinou len $k$ starým rodičom.

\section{Výsledky a diskusia: vztahy medzi hierarchiou v detskej skupine, exekutívnymi funkciami a socioekonomickým statusom}

\section{Testovanie predpokladov štatistických analýz}

Na úvod niekol'ko slov o štatistických metódach. Napriek tomu, že najmä v posledných dvoch desat'ročiach bol zaznamenaný až explozívny pokrok moderných robustných štatistických metód, tie sú v sociálnych vedách vel'mi málo využívané napriek tomu, že bolo dokázané (Wilcox 2010), že klasické parametrické metódy (t-test, ANOVA, regresia), ako aj klasické non-parametrické testy (Mann-Whitney test, Wilcoxonov test) sú mimoriadne nepresné aj pri malých odchýlkach od predpokladov (prítomnost' extrémnych hodnôt, non-normalita, heteroskedasticita), alebo majú vel'mi nízku štatistickú silu. V súčasnosti zrejme nejestvujú iné 
dôvody pre nevyužívanie moderných robustných metód než konzervatívnost' výučby a publikačných peer-review politík, ako aj integrácia a dostupnost' klasických zastaraných metód v používaných komerčných softvéroch ako SPSS. Najmä pri testovaní predpokladov by malo byt' povinne vyžadované použitie robustných metód - je zjavne nezmyselné a absurdné, aby sa pri overovaní predpokladov normality, extrémnych hodnôt či homoskedasticity používali testy (či dokonca histogramy alebo boxploty), ktoré samy nie sú odolné práve voči porušeniam normality či extrémnym hodnotám. Všetky štatistické analýzy $\mathrm{v}$ tomto článku boli vykonané v programe R, verzia 3.0.3., package WRS (Wilcox 2012).

Grafy rozloženia škál (kernel density, obrázok 1) ukazujú, že v škále „HTKS“ (exekutívne funkcie) sa určite vyskytuje problém s extrémnymi hodnotami.

\section{Obrázok 1}

\section{hierarchia}

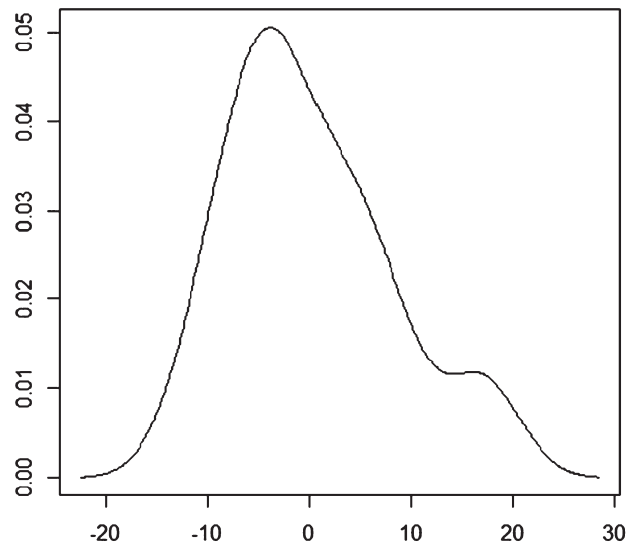

\section{skóre HTKS}

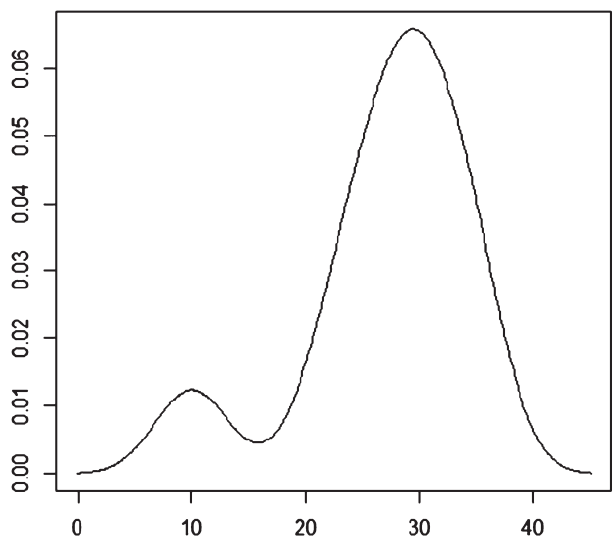

Robustný test normality (robustný Jarque-Bera test) skutočne potvrdil, že škála „HTKS“ nemá normálne rozloženie $\left(\chi_{(2)}^{2}=16,11, \mathrm{p}<0,001\right)$, škála „hierarchia“ má normálne rozloženie $\left(\chi_{(2)}^{2}=1,71, \mathrm{p}<0,43\right)$. Robustná metóda detekcie extrémnych hodnôt (median adjusted difference, Wilcox 2012: 97) ukázala, že v oboch škálach sa vyskytujú dve extrémne hodnoty: v škále „HTKS“ ide o dve najmladšie deti s najnižším skóre (trojročné, ktorých skóre bolo 9 a 11, pričom d'alšie skóre bolo 21): tieto dve najmenšie deti zjavne nemajú natol'ko rozvinuté exekutívne funkcie, aby zvládli test HTKS. V škále „hierachia“ sú extrémnymi hodnotami deti s najvyšším skóre (18 a 16, pričom d'alšie skóre je 9). Tieto deti však nebudeme z analýzy vyrad'ovat', ale budú použité robustné štatistické metódy, aby tieto hodnoty neskreslili výsledky analýzy. Aby sme objasnili dôležitost' použitia robustných metód: ak máme extrémne hodnoty tohto typu, môže sa stat', že napríklad (nerobustná) Pearsonova korelácia bude dramaticky skreslená - môže byt' signifikantná, hoci celý efekt môže byt' vytvorený práve a len týmito extrémnymi hodnotami. Vo vel'kej väčšine publikovaných článkov 
používajúcich klasické štatistické metódy sa bud' nedozvieme nič o testovaní predpokladov, alebo sa predpoklady testujú nerobustnými metódami.

Takisto (vzhl'adom na ponechanie výsledkov týchto detí v oboch škálach) bude použitá robustná one-way ANOVA na overenie vplyvu socioekonomického statusu, ako aj robustná analýza kontrastov medzi skupinami SES.

\section{Korelácia hierarchie v detskej skupine a exekutívnych funkcií}

Ako už bolo uvedené, vzhl'adom na non-normálne rozloženie jednej zo škál (HTKS) a prítomnost' extrémnych hodnôt v oboch škálach použijeme robustný odhad korelácie, a to ,,percentage bend correlation" (Wilcox 1994, 2012: 446-447). Korelácia medzi exekutívnymi funkciami a hierarchiou $\mathrm{v}$ detskej skupine je vel'mi signifikantná $\left(\mathrm{r}_{\mathrm{pb}}=0,64, \mathrm{~T}=3,53, \mathrm{p}<\right.$ 0,0025). Ked'že $\mathrm{r}_{\mathrm{pb}}$ (jej hodnotu, $v$ tomto prípade 0,64 ) nie je vhodné používat' ako ekvivalent magnitúdy korelácie $\rho$ ekvivalentný Pearsonovej korelácii, uvádzame takýto porovnatel'ný odhad prostredníctvom robustného určenia Pearsonovej korelácie cez percentilový bootstrap: $\mathrm{r}=0,49$ (95\% percentile bootstrap CI: 0,25-0,76). Dá sa teda vyslovit’ záver, že medzi exekutívnymi funkciami detí a hierarchiou v detskej skupine je vel'mi signifikantná pozitívna korelácia: deti s vysokým skóre v exekutívnych funkciách sa nachádzajú na vyšších pozíciách v sociálnej hierarchii detskej skupiny.

\section{Vztah hierarchie v detskej skupine a socioekonomického statusu}

Ked’že socioekonomický status (SES) je trojúrovňový faktor, na analýzu jeho vzt’ahu k hierarchii v detskej skupine bude použitý robustný ekvivalent one-way ANOVA, a to Welchova metóda s 20\% trimovanými priemermi, o ktorej simulácie ukázali, že si počína pomerne presne aj v prítomnosti extrémnych hodnôt (Wilcox 2012: 293). Tento test ukázal, že SES nemá signifikantný vplyv na hierarchiu $\mathrm{v}$ detskej skupine $\left(\mathrm{F}_{(2-6,37)}=4,15, \mathrm{p}=0,07\right)$. Pre porovnanie a zároveň ilustráciu nevyhnutnosti používania robustných metód: klasická ANOVA v SPSS poskytuje úplne opačný výsledok: ukazuje, že SES má signifikantný vplyv $\left(\mathrm{F}_{(2-20)}=6,82, \mathrm{p}<0,007\right)$ - úroveň signifikancie je dokonca desat'násobne menšia. Avšak ked' vyradíme $\mathrm{z}$ analýzy dve deti, ktorých skóre $\mathrm{v}$ hierarchii predstavuje extrémne hodnoty, klasická ANOVA v SPSS poskytne výrazne odlišný výsledok, v súlade s robustnou metódou: $\mathrm{F}_{(2-}$ ${ }_{18)}=2,59, \mathrm{p}=0,11$. Vidíme teda, že celý efekt zdanlivo vel'kej signifikancie spôsobujú (pri použití klasickej metódy) iba dve extrémne hodnoty. Robustná a presná metóda, ktorá počíta $\mathrm{s}$ extrémnymi hodnotami (a ako vieme, tie sú v dátach z reálneho sveta skôr pravidlom než výnimkou), teda môže viest' k úplne rozdielnym výsledkom a následne samozrejme aj k rozdielnej interpretácii zamietnutia hypotézy.

Robustná analýza kontrastov (percentilný bootstrap s 20\% trimovanými priemermi, Wilcox 2012: 329) medzi jednotlivými skupinami SES však ukazuje diferencovanejšiu interpretáciu: kontrasty medzi det'mi so stredným a nižším SES a vyšším a stredným SES nie sú signifikantné, no signifikantný je kontrast medzi det’mi s vyšším SES a nižším SES. Inými slovami, deti s vyšším SES sa nachádzajú na vyšších pozíciách v hierarchii iba v porovnaní s det'mi s nižším SES. Nedá sa však povedat', že deti s vyšším SES sa automaticky nachádzajú 
na najvyšších pozíciách a deti s nižším SES na najnižších: skôr ide o to, že diet’a s vyšším SES má vyššiu pravdepodobnost', že bude v hierarchickej pozícii vyššie než diet'a s nižším SES (no diet'a s vyšším SES nemá vyššiu pravdepodobnost', že bude v hierarchicky vyššej pozícii než diet'a so stredným SES, a takisto diet’a so stredným SES nemá vyššiu pravdepodobnost', že bude v hierarchicky vyššej pozícii než diet'a s nižším SES).

\section{Vzt゙ah exekutívnych funkcií detí a socioekonomického statusu}

$\mathrm{Na}$ analýzu tohto vzt’ahu bude tiež použitý robustný ekvivalent one-way ANOVA, a to Welchova metóda s $20 \%$ trimovanými priemermi, o ktorej simulácie ukázali, že si počína pomerne presne aj v prítomnosti extrémnych hodnôt (Wilcox 2012: 293). Tento test ukázal, že SES nemá signifikantný vplyv na exekutívne funkcie $\mathrm{v}$ detskej skupine $\left(\mathrm{F}_{(2-7,21)}=3,27\right.$, $\mathrm{p}=0,10)$. Klasická ANOVA v SPSS v tomto prípade neposkytla úplne opačný výsledok a ukázala tiež, že SES nemá signifikantný vplyv $\left(\mathrm{F}_{(2-20)}=1,90, \mathrm{p}=0,18\right)$.

Robustná analýza kontrastov (percentilný bootstrap s $20 \%$ trimovanými priemermi, Wilcox 2012: 329) medzi jednotlivými skupinami SES však rovnako ako v prípade hierarchie ukazuje podobný vzor: kontrasty medzi det'mi so stredným a nižším SES a vyšším a stredným SES nie sú signifikantné, no signifikantný je kontrast medzi det’mi s vyšším SES a nižším SES. Inými slovami, deti s vyšším SES majú vyššie skóre v exekutívnych funkciách, no iba v porovnaní s det'mi s nižším SES. Nedá sa však povedat', že deti s vyšším SES majú automaticky najvyššie skóre v exekutívnych funkciách a deti s nižším SES najnižšie: skôr ide o to, že diet'a s vyšším SES má vyššiu pravdepodobnost' vyššieho skóre v exekutívnych funkciách než diet'a s nižším SES.

\section{Záver}

Výskum ukázal, že exekutívne funkcie detí signifikantne korelujú s hierarchiou v detskej skupine, no vplyv socioekonomického statusu či už na hierarchiu v detskej skupine alebo aj na samotné exekutívne funkcie je malý: deti s lepšie rozvinutými exekutívnymi funkciami sú v rámci hierarchického usporiadania vyššie ako deti s menej rozvinutými exekutívnymi funkciami, no nie kvôli tomu, že ich rodiny majú vyšší socioekonomický status. Dominantné deti demonštrujú svoje lepšie rozvinuté exekutívne funkcie a zároveň si ich rozvíjajú nie tým, z akých rodín pochádzajú, ale tým, že si dokážu obhájit’ svoje miesto v skupine, riadia iných a dávajú im príkazy, majú lepší prístup k žiadaným zdrojom v detskej skupine, v rámci ktorej si dokážu vybudovat' rešpekt, autoritu a uznanie. Práve exekutívne funkcie sú inkorporovaným, vteleným sociálnym habitusom, ktorý si deti nemôžu iba jednoducho ,priniest“، zo svojich rodín, nech je ich socioekonomické postavenie akékol'vek vysoké. Musia ho potvrdit', obhájit' a budovat' v každodenných interakciách so svojimi rovesníkmi.

Chceli by sme ešte uviest', čo tieto výsledky netvrdia: naša interpretácia netvrdí a priori, že socioekonomický status principiálne nemá vplyv na sociálnu hierarchiu v detskej skupine či na exekutívne funkcie (sociálny habitus) detí. Tvrdíme iba to, že vyšší (či nižší) socioekonomický status sa mechanicky neprenáša do štruktúry detskej skupiny - deti si musia svoju pozíciu v detskej skupine vybudovat' a udržiavat': nech už majú socioekonomický status 
(alebo sociálny habitus z rodín) akýkol'vek, musia sa presadit' a dynamicky presadzovat' v detskej skupine, ktorej podmienky sú zásadne iné než v rodine. Ich rovesníci sa nesprávajú ako rodičia či súrodenci a sociálny kapitál z rodiny sa nedá jednoducho konvertovat' na sociálny kapitál v detskej skupine. Je možné, a závisí to od podmienok v konkrétnej detskej skupine, že socioekonomický status bude mat' výrazný a signifikantný vplyv: no vždy a za každých okolností (a to je naša interpretácia a prínos do štúdií sociálneho správania detí) prostredníctvom interakcií v detskej skupine a vytvorenia nového sociálneho habitusu, adaptovaného na detskú skupinu.

Nechceme tvrdit' ani to, že exekutívne funkcie sú dostatočné na implementáciu sociálneho habitusu, ale iba slabšiu hypotézu - že sú nevyhnutné. Dominovat' nad inými det'mi, zhodnotit' príležitosti a možnosti, ako aj vyhodnotit' komplexnú siet' sociálnych vzt'ahov v detskej skupine predpokladá zo strany dominujúcich detí vel'ké nároky na pracovnú pamät', pozornost' a inhibičné schopnosti, ktoré ich odvrátia od rozptyl'ujúcich podnetov. Sociálny habitus v detskej skupine sa samozrejme nevyčerpáva len dominanciou a budovaním hierarchie: už viackrát sme spomenuli, že ide o vel'mi komplexný pojem, a sociálna hierarchia, založená na dominancii a behaviorálnom presadzovaní sa, ho nemôže vyčerpat'. Deti vstupujú do mnohých iných komplexných vzt’ahov, emocionálno-afektívnych i sociálnych - napríklad kliky a skupiny kamarátov, ktoré nemusia byt’ organizované v lineárnej hierarchii, alebo symbolická reputačná prestíž, ktorá tiež nemusí byt’ lineárne hierarchická.

Netvrdíme ani to, že socioekonomický status sa v spoločnosti nereprodukuje a detská skupina predstavuje akési revolučné miesto sociálnych interakcií, kde sa karty rozdávajú nanovo: detská skupina nevykonáva svoje interakcie v sociálnom vzduchoprázdne - socioekonomický status rodín však disciplinačnými praktikami presadzujú skôr inštitúcie: učitel'ky, vychovávatel'ky, no aj rodičia a iní dospelí, ako aj médiá, a ich spojený vplyv vôbec nie je marginálny (Kaščák 2006). Zdanlivo dominantný vplyv socioekonomického statusu na výsledky detí, na ich správanie a osudy je však produktom toho, že informácie o správaní a výsledkoch detí získavame od dospelých: učitel'ov, rodičov, vychovávatel'ov, psychológov. Chceme tým povedat', že deti nemôžu vo svojej rovesníckej skupine priamo presadzovat' socioekonomický status svojich rodín, pretože ten nie je nikdy neproblematicky a priamo inými det'mi uznaný, ako sa to často so samozrejmost'ou predpokladá. Avšak málokto sa obt'ažuje venovat' čas dôkladnému a dlhodobému pozorovaniu každodenných interakcií detí. Externá (a často aj interná) validita explanačných nástrojov, ktoré v sociálnych vedách používame, je preto pochybná: náš výskum ukazuje, že každodenné interakcie detí v detskej skupine sú ovel'a významnejším explanačným faktorom, ako sa doposial' predpokladalo.

\section{Literatura}

ALBERS, Paul a Han de VRIES. Elo-rating as a tool in the sequential estimation of dominance strengths. Animal Behaviour, 2001, roč. 61, č. 2, s. 489-495. ISSN 0003-3472.

BOURDIEU, Pierre. The Forms of Capital. In RICHARDSON, John (ed.). Handbook of Theory and Research for the Sociology of Education. New York: Greenwood, 1986, s. 241-258. ISBN 03-1323-529-5. 
BOURDIEU, Pierre a Jean-Claude PASSERON. Reproduction in Education, Society and Culture. 2. vyd. London: SAGE, 1990. ISBN 0-8039-8320-4.

BOURDIEU, Pierre. The Logic of Practice. Redwood: Stanford University Press, 1991. ISBN 08-0472-011-8.

BOURDIEU, Pierre. Teorie jednání. Praha: Karolinum, 1998. ISBN 80-7184-518-3.

CERULO, Karen (ed.). Culture in Mind: Toward a Sociology of Culture and Cognition, New York: Routledge, 2001. ISBN 041592944X.

CORSARO, William. We're Friends, Right?: Inside Kids' Culture. Washington: Joseph Henry Press, 2003. ISBN 03-0908-729-5.

DAVID, Herbert. Ranking from unbalanced paired-comparison data. Biometrika, 1987, roč. 74, č. 2, s. 432-436. ISSN 0006-3444.

DIAMOND, Adele. Executive Functions. Annual Review of Psychology, 2013, roč. 64, č. 1, s. 135-168. ISSN 0066-4308.

DIMAGGIO, Paul. Why Cognitive (and Cultural) Sociology Needs Cognitive Psychology. In CERULO, Karen (ed.). Culture in Mind: Toward a Sociology of Culture and Cognition. New York: Routledge, 2002, s. 274-281. ISBN 041592944X.

GAMMELL, Martin, Han de VRIES, Dómnhall JENNINGS, Caitriona CARLIN a Thomas HAYDEN. David's score: a more appropriate dominance ranking method than Clutton-Brock et al.'s index. Animal Behaviour, 2003, roč. 66, č. 3, s. 601-605. ISSN 0003-3472.

HIRSCHFELD, Lawrence. Why don't anthropologists like children? American Anthropologist, 2002, roč. 104, č. 2, s. 611-627. ISSN 1548-1433.

HYMEL, Shelley, Kenneth RUBIN, Lynda ROWDEN a Lucy LeMARE. Children's Peer Relationships: Longitudinal Prediction of Internalizing and Externalizing Problems from Middle to Late Childhood. Child Development, 1990, roč. 61, č. 6, s. 2004-2021. ISSN 1467-8624.

CHRISTENSEN, Pia a Allison JAMES (eds.). Research with Children: Perspectives and Practices. London: Falmer, 2008. ISBN 075070974X.

JAMESON, Kimberley, Michael APPLEBY a Linton FREEMAN. Finding an appropriate order for a hierarchy based on probabilistic dominance. Animal Behaviour, 1999, roč. 57, č. 5, s. 991-998. ISSN 0003-3472.

KANOVSKÝ, Martin a Ivana STRUKOVÁ. Vplyv sociálnej reputácie rodiny na správanie učitel’ov voči det'om 1. stupňa ZŠ. In KVĚTON, Petr a Veronika SOBOTKOVÁ (eds.). Sociální procesy a osobnost 2013. Brno: Psychologický ústav AV ČR, 2013.

KAŠČÁK, Ondrej. Moc školy. O formativnej sile organizácie. Trnava: Typi Universitatis Tyrnaviensis, 2006. ISBN 80-22409-05-7.

KATRŇÁK, Tomáš. Odsouzeni k manuální práci. Vzdělanostní reprodukce v dělnické rodině. Praha: Sociologické nakladatelství, 2004. ISBN 80-86429-29-6.

KILLEN, Melanie. Social and Moral Development in Early Childhood. In KURTINES, William a Jacob GERWITZ (eds.). Handbook of Moral Behavior and Development, Part 2: Research. New York: Psychology Press, 1991, s. 115-138. ISBN 08-05808-81-7.

LAREAU, Anette. Unequal childhoods: Class, race, and family life. Berkeley: University of California Press, 2011. ISBN 05-20271-42-4.

LIZARDO, Omar. The Cognitive Origins of Bourdieu's Habitus. Journal for the Theory of Social Behaviour, 2004, roč. 34, č. 4, s. 375-401. ISSN 1468-5914.

PONITZ, Cameron, Megan McCLELLAND, Abigail JEWKES a Carol CONNOR et al. Touch your toes! Developing a direct measure of behavioral regulation in early childhood. Early Childhood Research Quarterly, 2008, č. 23, s. 141-158. ISSN 0885-2006.

RUSSON, Anne a Barbara WAITE. Patterns of Dominance and Imitation in an Infant Peer Group. Ethology and Sociobiology, 1991, roč. 12, č. 1, s. 55-73. ISSN 0162-3095. 
WANLESS, Shannon, Megan McClELlAND, Mary ACOCK, Cameron PONITZ et al. Measuring behavioral regulation in four societies. Psychological Assessment, 2011, roč. 23, č. 2, s. 364-378. ISSN 1015-5759.

WILCOX, Rand. Fundamentals of Modern Statistical Methods. New York: Springer, 2010. ISBN 978-1-4419-5524-1.

WILCOX, Rand. Introduction to Robust Estimation and Hypothesis Testing. Amsterdam: Elsevier, 2012. ISBN 978-0-12-386983-8.

\section{Autor a autorka}

Martin Kanovský působí na Univerzitě Komenského v Bratislavě. Specializuje se na kognitivní antropologii, antropologii dětství a dějiny antropologie. Je autorem dvou monografií (Osobnosti a teórie sociálnej a kultúrnej antropológie, Štruktúra mýtov: štrukturálna antropológia Clauda Lévi-Straussa) a desítek vědeckých studií.

Kontakt: kanovsky@fses.uniba.sk

Monika Turanská je studentkou magisterského studijního programu sociální antropologie na Univerzitě Komenského v Bratislavě. Věnuje se kognitivní antropologii a antropologii dětství. 